\title{
ALCOHOL USE AND ITS CONSEQUENCES IN THE CZECH REPUBLIC
}

\author{
Viktor Mravčík ${ }^{1,2,3}$, Pavla Chomynová1, 2,3, Blanka Nechanská1, 3,4, Tereza Černíková1,2, Ladislav Csémyy, 5 \\ 'Department of Addictology, First Faculty of Medicine, Charles University and General University Hospital, Prague, Czech Republic \\ ${ }^{2}$ National Monitoring Centre for Drugs and Addiction, Office of the Government, Prague, Czech Republic \\ ${ }^{3}$ Centre for Epidemiological and Clinical Research on Addictions, National Institute of Mental Health, Klecany, Czech Republic \\ ${ }^{4}$ Institute of Health Information and Statistics of the Czech Republic, Prague, Czech Republic \\ ${ }^{5}$ National Institute of Public Health, Prague, Czech Republic
}

\section{SUMMARY}

Objective: Alcohol consumption is associated with substantial public health burden. This article summarises available information on the patterns and prevalence of alcohol use in the Czech Republic with a focus on the heavy alcohol use and its health and social consequences.

Methods: A non-systematic literature review was conducted. The data sources included primarily 3 series of surveys in the adult population, 2 series of surveys in the school population, routine monitoring system of per capita alcohol consumption, routine statistics on alcohol-related morbidity and mortality, and alcohol-related crime.

Results: In recent years the registered alcohol consumption in the Czech Republic has been very high; 9.8 litres of pure alcohol were consumed per capita in 2017. Recently, the prevalence of hazardous alcohol consumption in the adult population has reached $16.8-17.6 \%$ and harmful alcohol consumption $9.0-9.3 \%$. From $12 \%$ to $17 \%$ of adult population and $12 \%$ of adolescent population were heavy episodic drinkers. Alcohol-related disorders are disproportionately higher (2-3 times) among men. Mortality for alcohol-related causes fully attributable to alcohol $(A A F=100 \%)$ and their proportion in overall mortality is on increase.

Conclusions: Alcohol consumption as well as the prevalence of heavy episodic drinking in the Czech Republic belongs among the highest globally. On the other hand, declines in alcohol use have been recently observed among children and adolescents. Available data on alcohol-related morbidity indicate stable situation, though alcohol-related mortality is increasing. Alcohol-related burden is rather underestimated and evidencebased alcohol policy should be increasingly implemented.

Key words: alcohol, heavy alcohol use, alcohol-related harm

Address for correspondence: T. Černíková, National Monitoring Centre for Drugs and Addiction, Office of the Government of the Czech Republic, Nábřeži Edvarda Beneše 4, 11801 Prague 1, Czech Republic. E-mail: cernikova.tereza@vlada.cz

https://doi.org/10.21101/cejph.a5728

\section{INTRODUCTION}

Alcohol consumption is associated with substantial morbidity and mortality. In 2016, alcohol represented the 7th most important risk factor out of 84 analysed behavioural, environmental and occupational, and metabolic risks or clusters of risks with approx. 3 million deaths (5.3\% of all deaths) worldwide and 132.6 million disability-adjusted life years (DALYs) - i.e. $5.1 \%$ of all DALYs in that year. Mortality resulting from alcohol consumption is higher than that caused by diseases such as tuberculosis, HIV/AIDS and diabetes. Higher burden is observed among men (2.3 million deaths and 106.5 million DALYs) than women (0.7 million deaths and 26.1 million DALYs attributable to alcohol consumption). People of younger ages were disproportionately more affected by alcohol compared to older persons, and $13.5 \%$ of all deaths among those who are 20-39 years old are attributed to alcohol. The proportion of all deaths and DALYs attributable to alcohol consumption are highest in the WHO European Region with $10.1 \%$ of all deaths and $10.8 \%$ of all DALYs (1-3).
Alcohol-induced damage to the organism derives from its direct effect, as well as from its metabolism and the substances produced thereof (4). Alcohol-related morbidity and mortality is associated with more than 30 conditions of the International Classification of Diseases, 10th edition (ICD-10), for which alcohol is a necessary cause (such as alcohol use disorders, alcoholic liver disease or alcohol-induced pancreatitis) and other approx. 200 conditions (particularly infectious diseases, neoplasms, neuropsychiatric or cardiovascular diseases), for which alcohol is a component cause (5). The proportion of deaths attributable to alcohol has been estimated as $53 \%$ in liver cirrhosis in men (45\% in women), $37 \%$ in oral cavity and pharynx cancer in men ( $12 \%$ in women), $32 \%$ in pancreatitis in men (12\% in women), $17-31 \%$ in injuries in men ( $3-7 \%$ in women), $16 \%$ in epilepsy in men ( $6 \%$ in women), $15 \%$ in tuberculosis in men ( $5 \%$ in women), $14 \%$ in hypertension in men ( $4 \%$ in women), $14 \%$ in haemorrhagic stroke in men ( $7 \%$ in women), $13 \%$ in colorectal cancer in men ( $7 \%$ in women), or $7 \%$ in breast cancer in women (6). In total, alcohol contributed to $5.8 \%$ of all cancer deaths (7) and 
$4.5 \%$ of all cardiovascular deaths in 2012 (8). In 2016, of all deaths attributable to alcohol consumption worldwide, $28.7 \%$ were due to injuries, $21.3 \%$ due to digestive diseases, $19 \%$ due to cardiovascular diseases, $12.9 \%$ due to infectious diseases, and $12.6 \%$ due to cancers. About $49 \%$ of alcohol attributable DALYs were due to non-communicable and mental health conditions, and about $40 \%$ due to injuries (2).

In addition to health harms, alcohol is accountable for social harms related to disruption of consumer's social roles (family problems, affected relations with closed persons, decreased work performance), financial problems or aggression and criminal behaviour, though there are methodological issues how to measure and quantify the attribution of alcohol consumption to them (9, $10)$.

Apart from harms to consumer themselves, alcohol causes harms to others (AHTO). Though AHTO phenomenon has not been fully conceptualised yet, it covers the whole surrounding of the user, i.e. family and close people, community and society as a whole (social costs are then universal abstract expression of the societal burden), and it can be caused by closed person or family member as well as a stranger $(11,12)$. Specific AHTO is represented by foetal alcohol spectrum disorders and foetal alcohol syndrome caused by heavy alcohol use in pregnancy due to its teratogenicity $(13,14)$.

Heavy use over time is responsible for the majority of the alcohol-attributable burden of disease and mortality $(15,16)$. It has been estimated that in the EU, heavy drinking and alcohol dependence accounts for $77 \%$ and $71 \%$ of total alcohol mortality, respectively (17).

The excess morbidity and mortality in heavy alcohol drinkers has been documented in alcohol use disorder (18), pancreatitis (19), liver cirrhosis (20), atrial fibrillation (21), hypertension (22), ischaemic heart disease (23), stroke (24), infectious diseases such as tuberculosis $(25,26)$ or pneumonia $(27)$, violence-related or accidental injuries (28), cancers of various localisations such as oral cavity, pharynx, larynx, oesophagus, stomach, colorectum, breast, or prostate $(29,30)$. Heavy use over time is also responsible for the main social consequences of alcohol use (31).

There is a clear dose-response relationship with risk increasing steadily with alcohol consumption without any threshold. This is truth for all above mentioned health consequences except ischaemic heart diseases, ischaemic stroke and diabetes mellitus where curvilinear relationship with beneficial effect of light to moderate drinking without heavy drinking occasions was established $(32,33)$, and the curvilinear association was described also in some social consequences such as work absenteeism (34) and surprisingly also in other health conditions such as lung cancer (35). However, estimates showing assumed benefits of low and moderate alcohol consumptions can be significantly biased by study design and characteristics. Meta-analyses adjusting for these factors found that even low-volume alcohol consumption has no net mortality benefit compared to lifetime abstention or occasional drinking, and thus no dose of alcohol can be recommended as beneficial (36-38).

There is an increasingly growing consensus on how much is "too much", and how the heavy alcohol drinking should be defined. Based on average volume of consumed alcohol (ethanol) over time, the thresholds of $\geq 40 \mathrm{~g} /$ day of ethanol for men and $\geq 20 \mathrm{~g} /$ day for women (39), or $\geq 60 \mathrm{~g} /$ day for men and $\geq 40 \mathrm{~g} /$ day for women (17) have been used to define heavy drinking, amount corresponding to $\geq 3-5$ standard drinks per day for men and $\geq 1.5-3$ standard drinks for women, or $\geq 21$ drinks per week for men and $\geq 14$ drinks per week for women (40). In population surveys, average volume of alcohol is recently measured usually using a set of questions operationalised in the Beverage-Specific Frequency Quantity (BSFQ) method (41).

In addition to average consumption, heavy drinking is often defined as heavy episodic drinking (HED), i.e. regular drinking of excessive amount of alcohol defined usually as $\geq 60 \mathrm{~g}$ of pure alcohol, or 5 or more standard drinks in one occasion. HED can be defined for example as regular drinking of $\geq 5$ drinks on an occasion (31), or $\geq 5$ drinks at least 3 times a week (42) or once a month (2). But also irregular heavy drinking occasions are associated with increased health burden in otherwise light to moderate average consumption and should be discouraged $(23,40)$. In the Czech Republic, national guidelines define hazardous drinking as $>20 \mathrm{~g} /$ day $(>24 \mathrm{~g} /$ day in males and $>16 \mathrm{~g}$ /day for females) providing that there are at least 2 days a week without any alcohol consumption and maximum volume per occasion exceeds $40 \mathrm{~g}$ of ethanol (43). However, it should be emphasised again, that risk of negative consequences increases from any consumption (i.e. one drink a day) and that no alcohol dose can be recommended as beneficial or presented as safe (44).

Heavy alcohol use is often measured by symptoms related to alcohol use disorder, or alcohol abuse, harmful use or alcohol dependence, that are defined in diagnostic and classification manuals such as the Diagnostic and Statistical Manual of Mental Disorders (DSM) or the International Classification of Diseases (ICD) and include a set of behavioural, cognitive and physiological conditions such as craving, impaired control over use, disordered interpersonal relationships, dysfunctional emotions, harmful consequences, continued substance use despite harmful consequences, substance use priority over other activities, increased tolerance, and withdrawal syndrome $(45,46)$. Operationalised questions on these symptoms are part of screening tools such as the Alcohol Use Disorder Identification Test (AUDIT), CAGE questionnaire, Rapid Alcohol Problems Screen (RAPS), or Composite International Diagnostic Interview (CIDI)/MunichComposite International Diagnostic Interview (M-CIDI) (47-51), that are (sometimes together with questions on frequency of drinking and heavy drinking) used also in population surveys to estimate prevalence of harmful patterns of alcohol consumption and alcohol use disorders in a population (52).

This article summarises available information on the patterns and prevalence of alcohol use in the Czech Republic with a focus on the heavy alcohol use and its health and social consequences. Where available, time series data are shown in order to identify recent trends.

\section{MATERIALS AND METHODS}

A review was conducted that investigated the current epidemiological situation concerning alcohol use and its consequences in the Czech Republic with a focus on heavy alcohol use. A nonsystematic literature review was performed as any systematic reviews of Czech sources are practically impossible given the absence of good abstract and citation databases in Czech, and 
alcohol burden in the Czech Republic has not been systematically monitored and reported so far. Relevant publications and grey literature known to the authors were used to compile the list of possible indicators. The primary focus was on the results of national cross-sectional surveys carried out on representative population samples and on the data from national statistics, time-series data were compiled where possible. The data sources included 3 series of population surveys carried out regularly in the adult population, and 2 series of surveys in the school population, and routine monitoring systems of the Czech Statistical Office (CZSO) and the Institute of Health Information and Statistics of the Czech Republic (IHIS CR).

The National Institute of Public Health collects data on the prevalence of alcohol use, daily alcohol use and excessive alcohol drinking, defined as consumption of $\geq 60 \mathrm{~g}$ of alcohol on one occasion at least once a week or more often; the calculation of volume of alcohol consumed is based on the BSFQ method. The data collection of the study takes place every two years since 2012 in the framework of the Omnibus Survey on Opinions and Attitudes of Citizens of the Czech Republic on Issues Related to Health Care and Healthy Lifestyle (Citizen Survey). In the last wave of the data collection in 2016, a total of 1,861 respondents aged $15+$ years were selected in quota sampling, to be representative for the Czech population by gender, age and regions.

The National Monitoring Centre for Drugs and Addiction carries out a nationally representative general population survey called the National Survey on Substance Use (National Survey) every 4 years since 2012, applying a comparable methodology to the General Population Survey on Drug Use and Attitudes Towards Drug Use carried out in 2008. The last wave of the National Survey was carried out in 2016, the sample size reached 3,601 respondents aged $15+$. The respondents were selected in 3 -stage stratified random sampling, and results are representative for the population of the Czech Republic by gender, age, region and education. The survey provides information on prevalence of alcohol use in the population, daily alcohol use and excessive alcohol use defined as consumption of 5 or more glasses of alcoholic beverages on one occasion with a frequency of at least once a week or more often. Estimates on hazardous and harmful alcohol use are based on CAGE screening instrument used in the survey $(48,53)$.

The Institute of Health Information and Statistics of the Czech Republic in collaboration with the Czech Statistical Office carried out the European Health Interview Survey (EHIS) in 2014, which followed the EHIS survey from 2008. Altogether 6,373 respondents aged 15+ years were randomly selected from the list of households provided by the CZSO. Alcohol consumption was surveyed in the context of health determinants, covering the prevalence of alcohol use, daily consumption and excessive alcohol use defined as consumption of $\geq 60 \mathrm{~g}$ of alcohol on one occasion at least once a month in the last year.

The National Monitoring Centre for Drugs and Addiction in collaboration with the National Institute of Mental Health is responsible for regular data collection within the cross-sectional European School Survey Project on Alcohol and Other Drugs (ESPAD) focusing on substance use and risk behaviour among 16-year-old students. In the last wave of the survey in 2015, altogether 2,738 students born in 1999 in randomly selected 215 schools of all types across the Czech Republic were surveyed.
The questionnaire covered prevalence of alcohol use, frequency of alcohol consumption, binge drinking (i.e. drinking of 5 or more glasses of alcoholic beverages on one occasion), as well as alcohol intoxication.

The Institute of Active Lifestyle of the Palacky University in Olomouc participates in the regular WHO international project called Health Behaviour in School-aged Children (HBSC) that monitors health and lifestyle among 11, 13 and 15-year-old students. The latest wave of data collection took place in 2018 , however, only data from the previous survey in 2014 are available. Altogether 14,136 students from 3 grades participated in the survey in 2014 from 243 randomly selected schools. Prevalence of weekly alcohol use was surveyed, as well as lifetime alcohol intoxication.

The Czech Statistical Office monitors the registered consumption of alcoholic beverages. Consumption is measured as sales of domestic producers, imports are added and vice versa, the export of spirits is deducted, stocks in traders or households are not recorded. Methodology of CZSO may differ from the methodology of international organisations (WHO, OECD) since unrecorded consumption is not estimated and recalculation per 1 inhabitant covers the whole population $0+$. CZSO also collects and publish the data on divorces and their causes.

The Institute of Health Information and Statistics of the Czech Republic routinely collects data on morbidity and mortality in number of national health registers. The following registers were used (54):

- The National Register of Hospitalized Patients is a nationwide population register that includes information on hospitalization irrespective of the type of admission and termination (discharge, transfer, death).

- The Information System on Deaths is a general mortality register of the Czech Republic.

- The Register of Tuberculosis monitors all persons with detected active tuberculosis or other mycobacteriosis.

\section{RESULTS}

\section{Alcohol Consumption and Heavy Alcohol Use in Adult Population}

The consumption of alcohol in the Czech Republic has been very high, 170.6 litres of alcohol were consumed per 1 inhabitant in 2017 which corresponds to 9.8 litres of pure alcohol (just registered consumption, calculated per population of all ages and with national coefficients for calculation of pure ethanol). In average, 1 inhabitant consumed 144 litres of beer, 19 litres of wine and 7 litres of distillates in a year (55). Consumption of pure ethanol per 1 inhabitant has been stable over the last 15 years (Table 1).

Alcohol prevalence in lifetime has been reported by more than $96 \%$ of the population, and $82 \%$ of the adult population report alcohol use in the last year $(56,57)$. Higher prevalence of alcohol use has been reported by males (87-89\%) than females (76-78\%). About $70 \%$ of the adults report alcohol use in the last 30 days.

It is not only the prevalence of alcohol use in the Czech population that has been on a high level, but also the daily or almost daily alcohol consumption has been reported by a high proportion of the adult population aged $15+$ years, ranging between $6.1-9.5 \%$ 
Table 1. Consumption of alcohol in the Czech Republic per capita by type of alcoholic beverages, in litres of pure ethanol

\begin{tabular}{|l|c|c|c|c|c|c|c|c|c|c|c|c|c|c|}
\hline Alcoholic beverage & $\mathbf{2 0 0 4}$ & $\mathbf{2 0 0 5}$ & $\mathbf{2 0 0 6}$ & $\mathbf{2 0 0 7}$ & $\mathbf{2 0 0 8}$ & $\mathbf{2 0 0 9}$ & $\mathbf{2 0 1 0}$ & $\mathbf{2 0 1 1}$ & $\mathbf{2 0 1 2}$ & $\mathbf{2 0 1 3}$ & $\mathbf{2 0 1 4}$ & $\mathbf{2 0 1 5}$ & $\mathbf{2 0 1 6}$ & $\mathbf{2 0 1 7}$ \\
\hline Spirits & 3.0 & 3.1 & 3.2 & 3.3 & 3.2 & 3.3 & 2.8 & 2.8 & 2.7 & 2.6 & 2.7 & 2.8 & 2.8 & 2.8 \\
\hline Wine & 1.9 & 1.9 & 2.0 & 2.1 & 2.1 & 2.1 & 2.2 & 2.2 & 2.3 & 2.2 & 2.3 & 2.2 & 2.3 & 2.2 \\
\hline Bier & 4.9 & 5.2 & 5.0 & 5.0 & 5.1 & 5.0 & 4.8 & 4.8 & 5.0 & 5.0 & 5.0 & 4.8 & 4.9 & 4.8 \\
\hline Total & 9.8 & 10.2 & 10.2 & 10.4 & 10.4 & 10.4 & 9.8 & 9.8 & 9.9 & 9.8 & 10.1 & 9.8 & 9.9 & 9.8 \\
\hline
\end{tabular}

Source: Czech Statistical Office (55)

Table 2. Prevalence of alcohol use in the adult population in the Czech Republic by gender, various indicators

\begin{tabular}{|c|c|c|c|c|c|c|c|c|}
\hline \multirow[t]{2}{*}{$\begin{array}{l}\text { Indicators } \\
\text { of alcohol } \\
\text { use in adult } \\
\text { population }\end{array}$} & \multicolumn{3}{|c|}{$\begin{array}{c}\text { Citizen Survey* } \\
\text { (population aged } 15+\text { ) }\end{array}$} & \multicolumn{3}{|c|}{$\begin{array}{l}\text { National Survey on Substance Use** } \\
\text { (population aged } 15-64 \text { in } 2008 \text { and 2012, and } \\
15+\text { in 2016) }\end{array}$} & \multicolumn{2}{|c|}{$\begin{array}{l}\text { European Health Interview } \\
\text { Survey**} \\
\text { (population aged } 15-64 \text { in } \\
2008 \text { and } 15+\text { in 2014) }\end{array}$} \\
\hline & 2012 & 2014 & 2016 & 2008 & 2012 & 2016 & 2008 & 2014 \\
\hline \multicolumn{9}{|c|}{ Last year prevalence (\%) } \\
\hline Total & 86.5 & 87.1 & 82.5 & 90.5 & 84.0 & 80.1 & n.a. & n.a. \\
\hline Males & 89.2 & 90.4 & 87.0 & 94.4 & 88.8 & 88.0 & 91.1 & n.a. \\
\hline Females & 83.9 & 83.9 & 78.3 & 86.6 & 79.4 & 72.5 & 77.2 & n.a. \\
\hline \multicolumn{9}{|c|}{ Daily or almost daily use (\%) } \\
\hline Total & 6.6 & 5.1 & 6.1 & 6.6 & 5.2 & 7.7 & n.a. & 9.5 \\
\hline Males & 10.2 & 7.7 & 9.2 & 10.7 & 9.1 & 13.1 & 15.6 & 16.4 \\
\hline Females & 3.1 & 2.6 & 3.1 & 2.4 & 1.4 & 2.6 & 3.3 & 3.2 \\
\hline \multicolumn{9}{|c|}{ Heavy episodic drinking (\%) } \\
\hline Total & 18.3 & 17.0 & 12.6 & 16.4 & 12.9 & 12.3 & n.a. & 17.3 \\
\hline Males & 27.8 & 24.8 & 20.4 & 23.8 & 21.1 & 19.4 & 23.6 & 25.0 \\
\hline Females & 8.7 & 9.2 & 5.2 & 8.3 & 4.9 & 5.6 & 7.6 & 9.2 \\
\hline
\end{tabular}

* Heavy episodic drinking is defined as the intake of 60 or more grams of alcohol in one occasion at least once a week.

** Heavy episodic drinking is defined as drinking 5 or more glasses of alcohol in one occasion at least once a week.

${ }^{* * *}$ Heavy episodic drinking in 2008 was defined as drinking 6 or more glasses of alcohol, in 2014 as the intake of 60 or more grams of alcohol in one occasion at least once a month.

Source: Chomynová (58), Běláčková et al. (59), Chomynová and Mravčík (57), Institute of Health Information and Statistics of the Czech Republic (60), Institute of Health Information and Statistics of the Czech Republic (61), Daňková (62), Váňová et al. (56)

n.a. - not available

according to the surveys available (Table 2). The daily alcohol use has been significantly higher among males.

Excessive alcohol drinking, or heavy episodic drinking, has been even more prevalent in the Czech adult population than daily consumption. The definition of HED differs between surveys making the comparison and trends surveillance more complicated. While the National Survey on Substance Use in 2016 surveyed consumption of 5 or more glasses of alcohol on one occasion (amount corresponding to $60-80 \mathrm{~g}$ of pure ethanol) with the frequency of once a week or more often, the European Health Interview Survey in 2014 questioned consumption of 60 or more grams of pure alcohol on one occasion with the frequency of at least once a month or more often (i.e. covering a wider spectrum of heavy alcohol use in terms of the frequency of use). Taking into account the differences in definitions, frequent heavy alcohol use was reported by $12.3 \%$ and $17.3 \%$ of the population, respectively. In the Citizen Survey in 2016, the excessive alcohol use was defined as consumption of 60 or more grams of alcohol on one occasion with the frequency of at least once a week, reported a prevalence of $12.6 \%$ of excessive alcohol use in the adult population.
Regardless the definition used, the excessive alcohol use has been consistently 3 times higher among males than females in all surveys. Significant differences were observed in the alcohol use by age groups - while the use of excessive amounts of alcohol on one occasion has been much more prevalent among younger age groups, especially among young adults (aged 15-34 years), the daily alcohol use has been increasing with age, being the highest among 55-64-year-olds and 65 and older respondents (Fig. 1).

The nation-wide representative population surveys have included screening instruments for the estimates of heavy (hazardous and harmful) alcohol use. The National Institute of Public Health in the bi-annual omnibus Citizen Survey uses the average daily dose of pure alcohol based on BSFQ method to estimate the hazardous and harmful alcohol use in line with the WHO/OECD methodology $(63,64)$. Four categories of risk drinking are defined as follows: abstainers; drinkers at low risk (below $20 \mathrm{~g}$ of pure alcohol daily for women and $40 \mathrm{~g}$ for men); hazardous consumption, i.e. alcohol use at risk for health $(\geq 20-40 \mathrm{~g}$ for women and $\geq 40-60 \mathrm{~g}$ for men); and harmful use, i.e. alcohol consumption that is already causing harm to the drinker, who may also have symptoms of dependence ( $\geq 40 \mathrm{~g}$ for women and $\geq 60 \mathrm{~g}$ for men). 


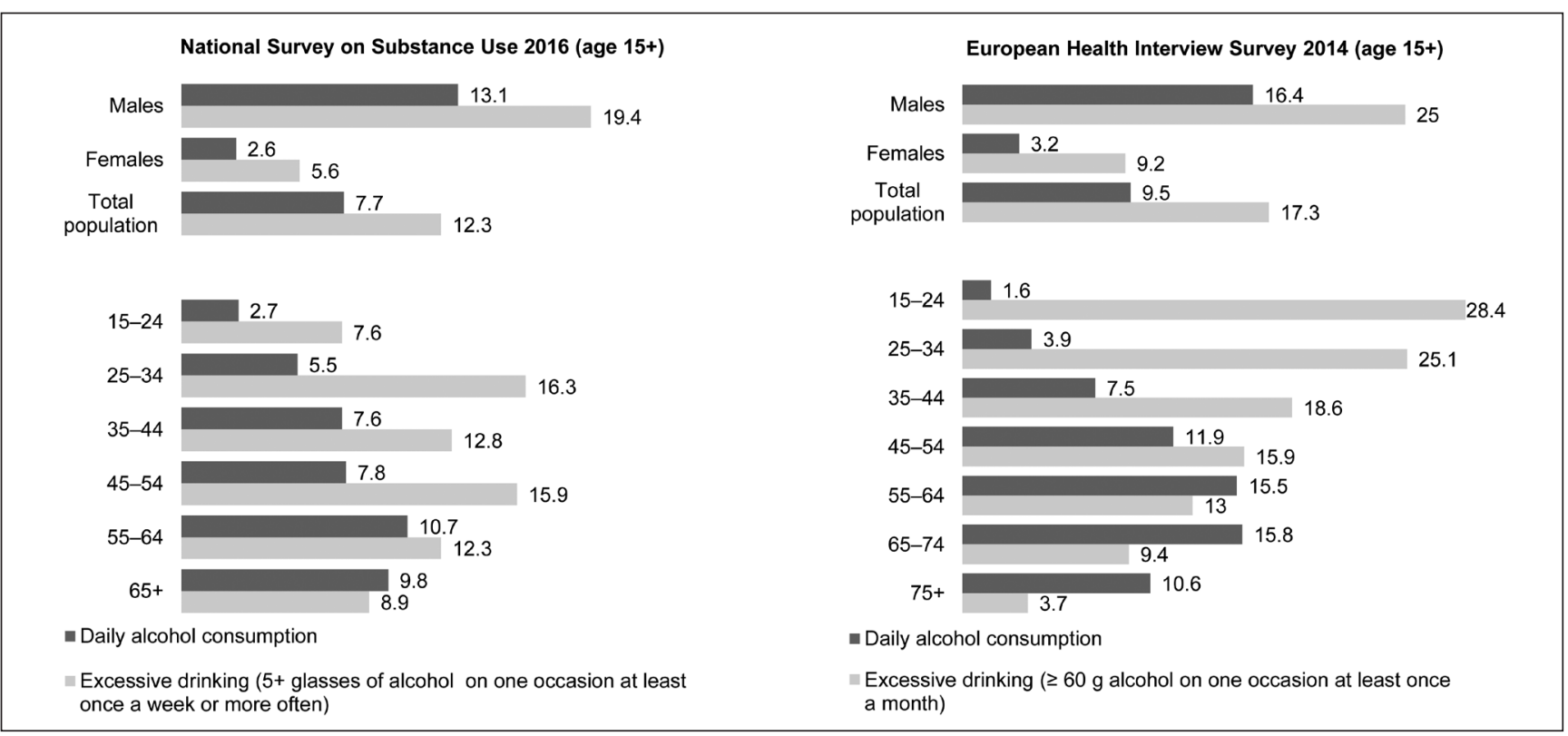

Fig. 1. Daily alcohol use and excessive drinking in the adult population aged 15+ by gender and age groups (\%).

Source: Chomynová and Mravčík (57), Daňková (62)

The National Survey on Substance Use carried out in 2012 and 2016 included the CAGE screening instrument for the estimates of problem alcohol use, a 4-item scale focusing on problems related to alcohol consumption in the last 12 months $(48,53)$. Positive answers were summed up providing a score of $0-4$ points, respondents reaching score of 1 point indicated hazardous drinking, and 2 or more points indicated harmful alcohol consumption.

The results of both approaches provide comparable results on prevalence of hazardous and harmful drinking in the adult population, reaching $7.8-8.3 \%$ for hazardous alcohol consumption and 9.0-9.3\% for harmful alcohol consumption, 16.8-17.6\% hazardous and harmful drinking together in 2016 (Table 3). The prevalence of hazardous and harmful drinking has been 2-3 times higher among males than females. Trend data based on both the Citizen Survey and National Survey show an increase in prevalence of hazardous and harmful drinking in the population between 2012 and 2016 (Fig. 2). When extrapolated to the adult population of the Czech Republic, the estimates of hazardous and harmful drinking together correspond to almost 1.5 million people (95\% CI: $1.39-1.62$ million), among them 800 thousand (95\% CI: $720-890$ thousand) exhibit symptoms of harmful alcohol use.

\section{Prevalence and Patterns of Alcohol Use among Ado- lescents}

Alcohol use has belonged among the most prevalent risk behaviours in the adolescent population as well. Within the HBSC study in 2014, the alcohol consumption in the last 30 days was reported by $8 \%$ girls and $15 \%$ boys, $19 \%$ girls and $28 \%$ boys, and $48 \%$ girls and $52 \%$ boys in the age of 11,13 , and 15 , respectively (65). According to the ESPAD study carried out in 2015 and $2016,69 \%$ and $65 \%$ of the 16 -year-olds, respectively, reported any alcohol use in the last 30 days (66).

Table 3. Prevalence of hazardous and harmful drinking in the adult population of the Czech Republic by gender

\begin{tabular}{|c|c|c|c|c|c|c|}
\hline \multirow{2}{*}{$\begin{array}{l}\text { Indicators of al- } \\
\text { cohol use in adult } \\
\text { population }\end{array}$} & \multicolumn{3}{|c|}{$\begin{array}{c}\text { Citizen Survey* } \\
\text { (population aged } 15+\text { ) }\end{array}$} & \multicolumn{3}{|c|}{$\begin{array}{l}\text { National Survey on Substance Use } \\
\text { (population aged } 15-64 \text { in } 2012 \text { and } 15+\text { in 2016) }\end{array}$} \\
\hline & 2012 & 2014 & 2016 & 2008 & 2012 & 2016 \\
\hline \multicolumn{7}{|c|}{ Hazardous drinking (\%) } \\
\hline Total & 6.9 & 7.2 & 8.3 & n.a. & 8.7 & 7.8 \\
\hline Males & 7.7 & 8.0 & 9.0 & n.a. & 9.8 & 11.0 \\
\hline Females & 6.7 & 6.4 & 7.5 & n.a. & 7.8 & 4.8 \\
\hline \multicolumn{7}{|l|}{ Harmful drinking (\%) } \\
\hline Total & 7.1 & 6.0 & 9.3 & n.a. & 8.3 & 9.0 \\
\hline Males & 9.9 & 7.4 & 12.9 & n.a. & 11.8 & 14.5 \\
\hline Females & 4.3 & 4.7 & 5.9 & n.a. & 4.7 & 3.8 \\
\hline
\end{tabular}

*Hazardous drinking is defined as $>20 \mathrm{~g}$ and $\leq 40 \mathrm{~g}$ of pure alcohol a day in average in females and $>40 \mathrm{~g}$ and $\leq 60 \mathrm{~g} /$ day in males, harmful drinking as $>40 \mathrm{~g}$ of pure alcohol a day in females and $>60 \mathrm{~g} /$ day in males.

**Based on CAGE screening instrument, hazardous drinking is defined as scoring 1 point, and harmful drinking as scoring 2 or more points on the scale.

Source: Chomynová (58), Běláčková et al. (59), Chomynová and Mravčík (57), Váňová et al. (56) 


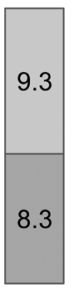

2016
National Survey

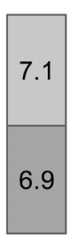

2012

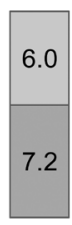

2014 $\square$ Hazardous drinking

$\square$ Harmful drinking
Fig. 2. Prevalence of hazardous and harmful drinking in the adult population of the Czech Republic (\%).

Data for Citizen Survey refer to population aged 15+ years. Trend data for National Survey on Substance Use are only available for 15-64 years old age group.

Source: Chomynová (58), Běláčková et al. (59), Chomynová and Mravčík (57), Váňová et al. (56)

The adolescent population has also reported relatively high levels of binge drinking and other forms of heavy alcohol use. According to the ESPAD study, $40-42 \%$ of the 16-year-olds reported drinking 5 or more glasses of alcohol on one occasion at least once in the last month (Fig. 3), while $12 \%$ of the students ( $14 \%$ of boys and $10 \%$ of girls) were frequent binge drinkers, reporting drinking high volumes of alcohol with a frequency of at least 3 times in the last month (approx. once a week or more often). Alcohol intoxication (subjectively perceived) in the last 30 days was reported by $15 \%$ of the 16 -years-olds ( $18 \%$ of boys and $12 \%$ of girls) in 2015 and 14\% in 2016, and repeated intoxication (3 or more times in the last 30 days) was reported by $2 \%$ of the students in 2015 and 2016. Alcohol intoxication was also surveyed in the HBSC study, however, the indicator was defined in a different way than in ESPAD. In HBSC, the repeated drunkenness in lifetime,

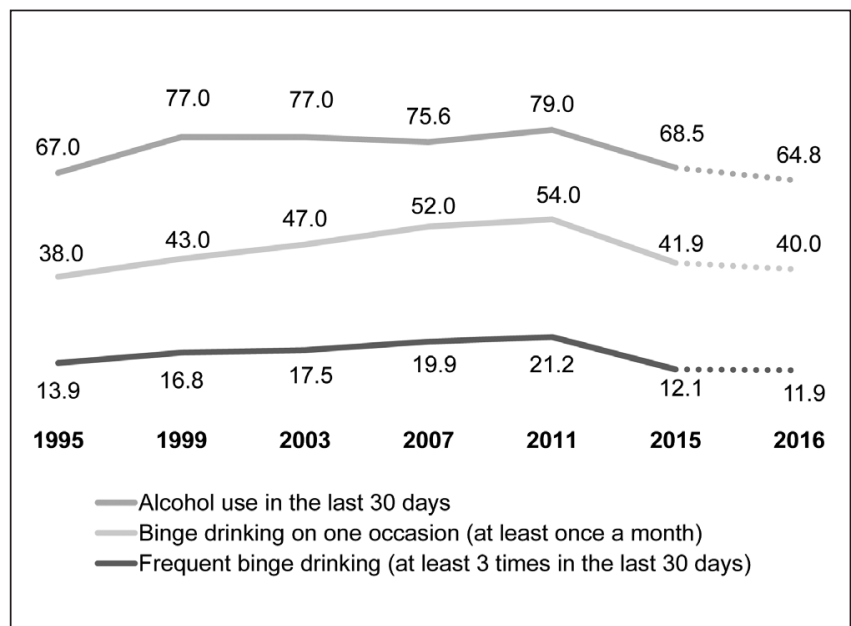

Fig. 3. Alcohol use among 16-year-olds, trends in 1995-2016, various indicators, ESPAD study (\%).

Source: Chomynová et al. (66)

i.e. intoxication experienced 2 times of more often in lifetime, was reported by $30 \%$ of the 15 -year-olds, but also by approximately $6 \%$ of the 13 -year-olds, and $1 \%$ of the 11 -year-olds (Fig. 4).

\section{Morbidity and Mortality}

Table 4 and Figure 5 provide trend data from the National Register of Hospitalized Patients on in-patient morbidity of conditions fully attributable to alcohol use, i.e. with $\mathrm{AAF}=100 \%$. Slightly decreasing trend can be observed that is mainly due to decrease in mental and behavioural disorders attributed to alcohol and alcohol intoxication.

There are limited routine information available on the morbidity of conditions with AAF $<100 \%$. Only available published data exist on association of alcohol with injuries from in-patient



Fig. 4. Repeated alcohol intoxication (2 or more times in lifetime) among 11, 13 and 15-year-old children, by gender- HBSC study (\%).

Source: Csémy et al. (65), Madarasová Gecková et al. (67) 
Table 4. Number of hospitalisations for conditions with $A A F=100 \%$

\begin{tabular}{|c|c|c|c|c|c|c|c|c|c|c|c|c|c|c|}
\hline Condition & dg. ICD-10 & 2005 & 2006 & 2007 & 2008 & 2009 & 2010 & 2011 & 2012 & 2013 & 2014 & 2015 & 2016 & 2017 \\
\hline $\begin{array}{l}\text { Mental and } \\
\text { behavioural disor- } \\
\text { ders attributed to } \\
\text { alcohol }\end{array}$ & F10 & 11,984 & 11,053 & 10,877 & 10,722 & 10,419 & 10,003 & 9,765 & 9,544 & 9,067 & 9,724 & 9,522 & 9,489 & 8,903 \\
\hline $\begin{array}{l}\text { Alcohol } \\
\text { intoxication }\end{array}$ & $\begin{array}{l}\text { T510, T511, } \\
\text { T519 }\end{array}$ & 1,229 & 1,192 & 1,163 & 1,132 & 922 & 735 & 724 & 835 & 623 & 568 & 436 & 465 & 465 \\
\hline $\begin{array}{l}\text { Degeneration of } \\
\text { nervous system } \\
\text { attributed to } \\
\text { alcohol }\end{array}$ & G312 & 67 & 64 & 63 & 91 & 81 & 63 & 84 & 83 & 88 & 94 & 90 & 105 & 112 \\
\hline $\begin{array}{l}\text { Alcoholic } \\
\text { polyneuropathy }\end{array}$ & G621 & 125 & 100 & 112 & 116 & 149 & 119 & 111 & 170 & 131 & 154 & 140 & 135 & 132 \\
\hline $\begin{array}{l}\text { Alcoholic liver } \\
\text { disease }\end{array}$ & K70 & 4,499 & 4,300 & 4,667 & 4,752 & 4,628 & 4,742 & 4,530 & 4,819 & 4,168 & 4,294 & 4,310 & 4,237 & 4,417 \\
\hline $\begin{array}{l}\text { Alcohol-induced } \\
\text { acute pancreatitis }\end{array}$ & K852 & 0 & 0 & 0 & 0 & 416 & 539 & 562 & 615 & 618 & 706 & 765 & 775 & 684 \\
\hline $\begin{array}{l}\text { Alcohol-induced } \\
\text { chronic } \\
\text { pancreatitis }\end{array}$ & K860 & 604 & 589 & 616 & 653 & 667 & 692 & 651 & 687 & 581 & 580 & 477 & 516 & 493 \\
\hline $\begin{array}{l}\text { Other alcohol- } \\
\text { related conditions } \\
\text { with } \mathrm{AAF}=100 \%\end{array}$ & $\begin{array}{l}\text { E244, } \\
\text { G721, } \\
\text { I426, K292, } \\
\text { O354, } \\
\text { P043, } \\
\text { Q860, R780 }\end{array}$ & 130 & 104 & 99 & 71 & 106 & 93 & 121 & 128 & 123 & 108 & 105 & 92 & 89 \\
\hline $\begin{array}{l}\text { Total conditions } \\
\text { with AAF }=100 \%\end{array}$ & & 18,638 & 17,402 & 17,597 & 17,537 & 17,388 & 16,986 & 16,548 & 16,881 & 15,399 & 16,228 & 15,845 & 15,814 & 15,295 \\
\hline Males & & 13,300 & 12,166 & 12,250 & 12,118 & 12,127 & 11,899 & 11,494 & 11,822 & 10,857 & 11,562 & 11,077 & 11,085 & 10,853 \\
\hline Females & & 5,338 & 5,236 & 5,347 & 5,419 & 5,261 & 5,087 & 5,054 & 5,059 & 4,542 & 4,666 & 4,768 & 4,729 & 4,442 \\
\hline
\end{tabular}

Source: National Register of Hospitalized Patients

Table 5. Number and proportion of hospitalisations for injuries under influence of alcohol

\begin{tabular}{|l|c|c|c|c|c|c|c|c|c|c|c|c|c|}
\hline Year & $\mathbf{2 0 0 5}$ & $\mathbf{2 0 0 6}$ & $\mathbf{2 0 0 7}$ & $\mathbf{2 0 0 8}$ & $\mathbf{2 0 0 9}$ & $\mathbf{2 0 1 0}$ & $\mathbf{2 0 1 1}$ & $\mathbf{2 0 1 2}$ & $\mathbf{2 0 1 3}$ & $\mathbf{2 0 1 4}$ & $\mathbf{2 0 1 5}$ & $\mathbf{2 0 1 6}$ & $\mathbf{2 0 1 7}$ \\
\hline $\begin{array}{l}\text { Total number of injuries } \\
\text { (thousands) }\end{array}$ & 187.1 & $\mathbf{1 9 6 . 6}$ & $\mathbf{2 0 3 . 2}$ & $\mathbf{2 0 2 . 8}$ & $\mathbf{1 9 5 . 8}$ & $\mathbf{1 9 1 . 9}$ & $\mathbf{1 9 6 . 0}$ & $\mathbf{1 9 8 . 7}$ & $\mathbf{2 0 0 . 3}$ & $\mathbf{2 0 0 . 6}$ & 205.1 & 204.6 & 210.3 \\
\hline Under influence of alcohol & 5,845 & 5,216 & 5,878 & 6,650 & 6,974 & 6,615 & 6,807 & 7,190 & 7,049 & 7,611 & 7,384 & 6,855 & 6,485 \\
\hline Proportion (\%) & 2.9 & 2.7 & 3.1 & 3.4 & 3.5 & 3.3 & 3.4 & 3.5 & 3.4 & 3.6 & 3.5 & 3.3 & 3.1 \\
\hline
\end{tabular}

Influence of alcohol on injury was defined as concurrent dg. F100 or T510 or T519 together with any dg. for injury (S00-T35).

Source: National Register of Hospitalized Patients

Table 6. Number and proportion of newly diagnosed cases of tuberculosis in heavy alcohol users

\begin{tabular}{|c|c|c|c|c|c|c|c|c|c|c|c|c|c|}
\hline Year & 2005 & 2006 & 2007 & 2008 & 2009 & 2010 & 2011 & 2012 & 2013 & 2014 & 2015 & 2016 & 2017 \\
\hline $\begin{array}{l}\text { Total number of TBC } \\
\text { cases (thousands) }\end{array}$ & 1,007 & 973 & 871 & 879 & 710 & 680 & 609 & 611 & 502 & 514 & 518 & 517 & 505 \\
\hline $\begin{array}{l}\text { TBC cases in heavy } \\
\text { alcohol users }\end{array}$ & 120 & 111 & 128 & 115 & 89 & 81 & 86 & 71 & 63 & 65 & 84 & 69 & 78 \\
\hline Proportion (\%) & 11.9 & 11.4 & 14.7 & 13.1 & 12.5 & 11.9 & 14.1 & 11.6 & 12.5 & 12.6 & 16.2 & 13.3 & 15.4 \\
\hline
\end{tabular}

Heavy alcohol use is not specifically defined in the surveillance system.

Source: Register of Tuberculosis 




Fig. 5. Number of hospitalisations for conditions with $A A F=100 \%$.

Source: National Register of Hospitalized Patients

register and newly diagnosed cases in heavy alcohol users from surveillance system of tuberculosis (Table 5 and 6). The number of alcohol-related injuries demanding in-patient treatment fluctuates in a range of 5-7 thousand cases a year. The number of total cases, as well as alcohol-related cases of tuberculosis, shows a decreasing trend with increasing alcohol-related proportion at the same time.

Mortality data are available from the Information System on Deaths for causes of deaths with AAF $=100 \%$ (Table 7 and Fig. 6). Mortality for alcohol-related causes and proportion of alcoholrelated causes of deaths in overall mortality has increased recently, mainly due to alcoholic liver diseases.
As regards morbidity and mortality for foetal alcohol spectrum disorders (FASD), there were 2 hospitalisations with $\mathrm{dg}$. foetus and new-born affected by maternal use of alcohol (dg. P043), of them 1 new-born died, and 9 hospitalisations for foetal alcohol syndrome (dysmorphic) (dg. Q860), none of them died, in 2005-2017.

Overall alcohol-related burden was estimated at the level of $6 \%$ of total mortality in 2010 ( $10 \%$ in men and $2 \%$ in women), which was approx. 6.5 thousand deaths annually (68). The biggest proportion of deaths was observed in older age groups, the highest relative burden was in the age group 35-44 years $(26 \%$ of total mortality in men and $17 \%$ in women).

Table 7. Mortality for conditions with $A A F=100 \%$

\begin{tabular}{|c|c|c|c|c|c|c|c|c|c|c|c|c|c|c|}
\hline Conditions & dg. ICD-10 & 2005 & 2006 & 2007 & 2008 & 2009 & 2010 & 2011 & 2012 & 2013 & 2014 & 2015 & 2016 & 2017 \\
\hline $\begin{array}{l}\text { Alcohol intoxica- } \\
\text { tion }\end{array}$ & $\begin{array}{l}\text { F10, T510, } \\
\text { T511, T519 }\end{array}$ & 416 & 347 & 343 & 368 & 354 & 322 & 316 & 317 & 292 & 322 & 342 & 415 & 370 \\
\hline $\begin{array}{l}\text { Alcoholic liver } \\
\text { disease }\end{array}$ & K70 & 1,085 & 1,035 & 1,240 & 1,261 & 1,224 & 1,276 & 1,241 & 1,297 & 1,382 & 1,324 & 1,381 & 1,308 & 1,495 \\
\hline $\begin{array}{l}\text { Other alcohol- } \\
\text { related conditions } \\
\text { with } \mathrm{AAF}=100 \%\end{array}$ & $\begin{array}{l}\text { E244, } \\
\text { G312, } \\
\text { G621, } \\
\text { G721, } \\
\text { I426, K292, } \\
\text { K852, K860, } \\
\text { O354, } \\
\text { P043, Q860 }\end{array}$ & 39 & 23 & 39 & 41 & 38 & 57 & 61 & 59 & 62 & 72 & 81 & 85 & 84 \\
\hline $\begin{array}{l}\text { Total conditions } \\
\text { with } A A F=100 \%\end{array}$ & & 1,540 & 1,405 & 1,622 & 1,670 & 1,616 & 1,655 & 1,618 & 1,673 & 1,736 & 1,718 & 1,804 & 1,808 & 1,949 \\
\hline Males & & 1,157 & 1,038 & 1,243 & 1,265 & 1,212 & 1,249 & 1,225 & 1,258 & 1,304 & 1,260 & 1,350 & 1,359 & 1,452 \\
\hline Females & & 383 & 367 & 379 & 405 & 404 & 406 & 393 & 415 & 432 & 458 & 454 & 449 & 497 \\
\hline $\begin{array}{l}\text { Mortality (per } \\
1,000 \text { inhabitants) }\end{array}$ & & 0.15 & 0.14 & 0.16 & 0.16 & 0.15 & 0.16 & 0.15 & 0.16 & 0.17 & 0.16 & 0.17 & 0.17 & 0.18 \\
\hline $\begin{array}{l}\text { Proportion of total } \\
\text { mortality }(\%)\end{array}$ & & 1.4 & 1.3 & 1.6 & 1.6 & 1.5 & 1.5 & 1.5 & 1.5 & 1.6 & 1.6 & 1.6 & 1.7 & 1.7 \\
\hline
\end{tabular}

Source: Information System on Deaths 


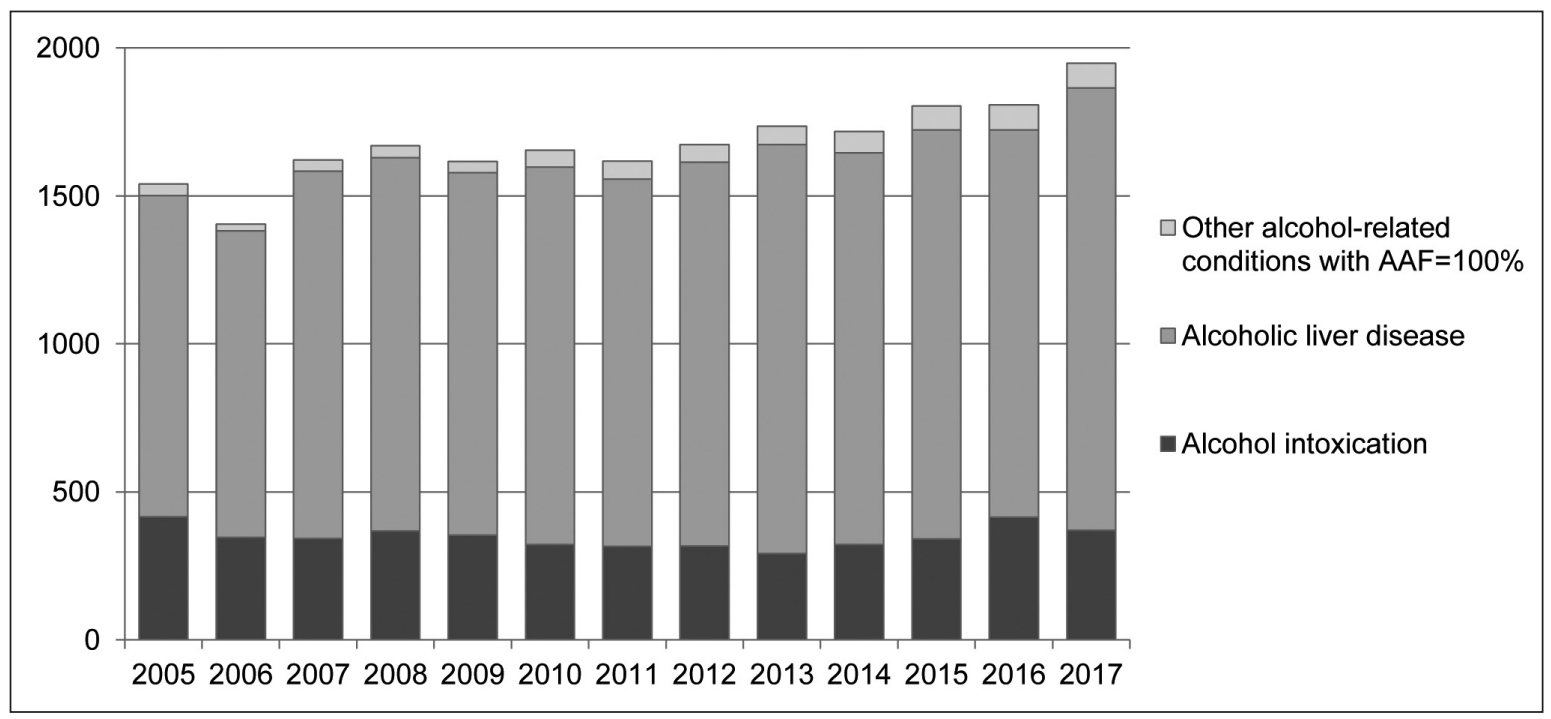

Fig. 6. Mortality for conditions with $A A F=100 \%$.

Source: Information System on Deaths

Table 8. Alcohol as reported cause of divorce

\begin{tabular}{|c|c|c|c|c|c|c|c|c|c|c|c|c|c|}
\hline Year & 2005 & 2006 & 2007 & 2008 & 2009 & 2010 & 2011 & 2012 & 2013 & 2014 & 2015 & 2016 & 2017 \\
\hline Number of divorces & 31,288 & 31,415 & 31,129 & 31,300 & 29,133 & 30,783 & 28,113 & 26,402 & 27,895 & 26,764 & 26,083 & 24,996 & 25,755 \\
\hline Alcohol as the cause & 1,514 & 1,326 & 1,153 & 1,040 & 988 & 989 & 768 & 691 & 633 & 554 & 466 & 447 & 496 \\
\hline $\begin{array}{l}\text { On the part of } \\
\text { male }\end{array}$ & 1,332 & 1,140 & 982 & 854 & 757 & 719 & 555 & 491 & 451 & 366 & 322 & 315 & 317 \\
\hline $\begin{array}{l}\text { O the part of } \\
\text { female }\end{array}$ & 182 & 186 & 171 & 186 & 231 & 270 & 213 & 200 & 182 & 188 & 144 & 132 & 179 \\
\hline Proportion (\%) & 4.84 & 4.22 & 3.70 & 3.32 & 3.39 & 3.21 & 2.73 & 2.62 & 2.27 & 2.07 & 1.79 & 1.79 & 1.93 \\
\hline
\end{tabular}

Source: Czech Statistical Office (69)

Table 9. Crime offences committed under influence of alcohol

\begin{tabular}{|c|c|c|c|c|c|c|c|c|c|c|c|c|c|}
\hline Year & 2005 & 2006 & 2007 & 2008 & 2009 & 2010 & 2011 & 2012 & 2013 & 2014 & 2015 & 2016 & 2017 \\
\hline $\begin{array}{l}\text { Cleared-up crime offences } \\
\text { in total (thousands) }\end{array}$ & 135.3 & 133.7 & 138.9 & 127.9 & 127.6 & 117.7 & 122.2 & 120.2 & 129.2 & 126.2 & 112.1 & 101.7 & 94.9 \\
\hline $\begin{array}{l}\text { Offences under influence of } \\
\text { alcohol (thousands) }\end{array}$ & 11.0 & 14.1 & 22.0 & 22.8 & 22.3 & 17.3 & 17.2 & 16.1 & 15.3 & 15.5 & 14.5 & 12.0 & 11.0 \\
\hline Proportion (\%) & 8.1 & 10.5 & 15.9 & 17.8 & 17.5 & 14.7 & 14.0 & 13.4 & 11.8 & 12.3 & 12.9 & 11.8 & 11.6 \\
\hline
\end{tabular}

Source: Police Presidium of the Police of the Czech Republic (74)

Table 10. Traffic accidents committed under influence of alcohol

\begin{tabular}{|c|c|c|c|c|c|c|c|c|c|c|c|c|c|c|}
\hline \multicolumn{2}{|l|}{ Year } & 2005 & 2006 & 2007 & 2008 & 2009 ** & 2010 & 2011 & 2012 & 2013 & 2014 & 2015 & 2016 & 2017 \\
\hline \multirow{3}{*}{$\begin{array}{l}\text { Number of } \\
\text { accidents }\end{array}$} & Total (thousand) & 195.9 & 196.5 & 199.3 & 188.0 & 182.7 & 160.4 & 74.8 & 75.5 & 75.1 & 81.4 & 84.4 & 85.9 & 93.1 \\
\hline & $\begin{array}{l}\text { Under influence } \\
\text { of alcohol }\end{array}$ & 8,192 & 6,807 & 7,266 & 7,252 & 5,725 & 5,015 & 5,242 & 4,974 & 4,686 & 4,637 & 4,544 & 4,373 & 4,251 \\
\hline & Proportion (\%) & 4.3 & 3.8 & 4.3 & 4.8 & 8.1 & 6.6 & 7.5 & 6.7 & 6.1 & 5.4 & 4.9 & 4.4 & 4.1 \\
\hline \multirow{3}{*}{$\begin{array}{l}\text { Number of } \\
\text { deceased } \\
\text { in traffic } \\
\text { accidents* }\end{array}$} & Total & 1,127 & 956 & 1,123 & 992 & 832 & 753 & 707 & 681 & 583 & 629 & 660 & 545 & 502 \\
\hline & $\begin{array}{l}\text { In accidents } \\
\text { under influence of } \\
\text { alcohol }\end{array}$ & 59 & 42 & 36 & 80 & 123 & 102 & 89 & 45 & 52 & 63 & 62 & 52 & 48 \\
\hline & Proportion (\%) & 5.2 & 4.3 & 3.2 & 8.1 & 14.9 & 13.5 & 12.6 & 6.6 & 9.0 & 10.0 & 9.4 & 9.5 & 9.6 \\
\hline
\end{tabular}

*Up to 24 hours following accidents. **Since 2009 , threshold of estimated damage for obligatory police investigation increased from 50 to 100 thousand CZK, which resulted in drop of reported traffic accidents.

Source: Directorate of Traffic Police Service of the Police Presidium of the Czech Republic (75) 


\section{Social Burden}

Excessive use of alcohol is routinely monitored as one of the causes of divorces in the Czech Republic. In 2017, alcohol was reported as a primary cause in 496 cases of divorces (1.9\%) (69). The proportion of alcohol-caused divorces has declined since 2005 (4.8\%), especially on the part of males. However, influence of alcohol might be recently underreported since there is increasing proportion of divorces when cause is not given $(6.4 \%$ in 2005 and $26.7 \%$ in 2017) (Table 8).

Alcohol was found a significant predictor of domestic violence. According to Nešpor and Csémy (70), alcohol was present in 2/3 of cases of domestic violence. Martinková et al. (71) found $72 \%$ of domestic violence offenders were under the influence of alcohol at the moment of the offence/attack. Recent research showed that risk of aggressive behaviour against partner increases with drinking frequency of 5 or more glasses of alcohol (OR $=15-20$ for daily excessive alcohol users compared to abstainers/rare alcohol users) (72). Extent of alcohol-related domestic violence in the Czech Republic is substantial taking into account that about $17-40 \%$ of women and $10-38 \%$ of men have experienced domestic violence in their lifetime and 2-9\% in the last 12 months (73).

Police of the Czech Republic collects information on the criminal offences undertaken under the influence of alcohol. A total of 11,023 offences under the influence of alcohol were committed in 2017 , i.e. $11.6 \%$ of all cleared-up offences, showing a decreasing trend over recent years (Table 9). The offences of endangerment under the influence of an addictive substance and inebriation (50\%), road traffic accidents $(17 \%)$ and intentional injury $(6 \%)$ accounted for the highest percentages of offences committed under the influence of alcohol.

In a separate information system, the police collect information about road traffic accidents including information on accidents with the proven guilt due to alcohol consumption (Table 10). There is likely an artificial influence to observed trends, however, both number of alcohol-related traffic accidents as well as alcoholrelated deaths due to traffic accidents confirm decreasing trend from police crime statistics above.

\section{Economic Costs of Alcohol Consumption}

Direct expenses of health care incurred by health insurance companies related to the treatment of substance use disorders are provided with a year's delay using health account statistics compiled according to the international System of Health Accounts. They comprise directly identifiable costs, i.e. those reported as incurred in relation to the treatment of primary diagnoses, and unidentifiable costs, with no link to a diagnosis, the proportion of which spent in relation to the F10-F19 diagnoses is estimated according to proportion of identifiable costs. The estimated volume of health insurance expenditures for the treatment of substance-related disorders (F10-F19) was CZK 1,818 million in 2016 (CZK 1,707 million in 2015, CZK 1,583 million in 2014), of which CZK 1,218 million (CZK 1,145 million in 2015, CZK 1,062 million in 2014) was issued for treatment of alcohol use disorders (F10), of them, amount consumed by the specialised addiction treatment departments of out-patient and hospital care reached 179 million (CZK 159 million in 2015, CZK 165 million in 2014), of which CZK 170 million for in-patient and CZK 8 million for out-patient care.
Table 11. Total social costs of alcohol consumption in the Czech Republic estimated in 2007 and 2016, in millions of CZK

\begin{tabular}{|l|c|c|}
\hline Category of costs & $\mathbf{2 0 0 7}$ & $\mathbf{2 0 1 6}$ \\
\hline Direct costs to prevention and treatment & $2,638.9$ & $13,830.3$ \\
\hline Direct costs to law-enforcement & $5,455.6$ & $6,308.4$ \\
\hline Other direct costs & 685.9 & 135.6 \\
\hline Direct costs in total & $8,780.4$ & $20,274.3$ \\
\hline Indirect health costs & $7,021.9$ & $28,987.3$ \\
\hline indirect law-enforcement costs & 552.6 & $1,961.5$ \\
\hline Indirect costs in total & $7,574.5$ & $30,948.8$ \\
\hline $\begin{array}{l}\text { Other costs not included above } \\
\text { (direct and indirect) }\end{array}$ & - & $5,348.3$ \\
\hline Total costs & $16,354.9$ & $56,571.4$ \\
\hline
\end{tabular}

Sources: Zábranský et al. (78), Mlčoch et al. (80)

Economic cost estimates of alcohol consumption using Cost of Illness (COI) methodology are available. They include direct costs, i.e. the cost of public budgets (both labelled and unlabelled), indirect costs, which represent mainly a loss of productivity due to morbidity, mortality and criminal careers, and possibly intangible costs, which represent emotional costs of distress $(76,77)$.

For 2007, COI were estimated for three main groups of addictive substances, i.e. tobacco, alcohol and illicit drugs. The aggregate social costs amounted to CZK 56.2 billion, of which tobacco accounted for CZK 33.1 billion (59.0\%), alcohol for CZK 16.4 billion (29.1\%) and illicit drugs for CZK 6.7 billion (11.9\%) (78). In 2010, the social cost of alcohol in the Czech Republic was estimated at CZK 19.6 billion (79). In 2016, social costs were estimated at CZK 56.6 billion (80), the comparison of 2007 and 2016 estimates is presented in Table 11. It should be borne in mind that the methodology of the two studies differs in details and that list of calculated direct and indirect costs in both studies is not identical. The intangible costs of alcohol have not yet been estimated in the Czech Republic. The economic cost of alcohol corresponded to $0.5 \%$ of gross domestic product (GDP) in 2007 , and to $1.2 \%$ in 2016 .

\section{DISCUSSION}

Our results indicate steady and very high level of alcohol consumption in the Czech Republic in recent years. Recorded annual consumption of alcohol in the Czech Republic reaches approx. 10 litres of pure ethanol per capita (all ages). According to WHO methodology, which differs and includes also unrecorded estimated consumption, it was 14.4 litres per capita (for population aged $15+$ years) in 2016 , which is by $47 \%$ more than the average of WHO European region (2) and one of the highest globally (81). High level of alcohol consumption in the Czech Republic has been recently and repeatedly found in population surveys with various geographic location and coverage $(82,83)$.

Excessive forms of alcohol intake are quite common in the Czech Republic. Trend data on alcohol consumption from population surveys show high levels of heavy alcohol use including heavy episodic drinking. The prevalence of HED (60 or more grams of alcohol in one occasion at least once a month) according 
to the $\mathrm{WHO}$ was $35.9 \%$, while the average of the European region was $26.4 \%$ in 2016 (2). Available data also indicate high population prevalence of hazardous and harmful drinking in the Czech Republic with comparable estimates of hazardous drinking in the adult population obtained with different methodologies applied.

In contrast to the adult population where the prevalence of alcohol use, including daily consumption and excessive alcohol use, has been stable over time with no signs of recent decline, the trends in the adolescent populations have showed significant declines in prevalence of alcohol use between 2010-2014 for HBSC and between 2011-2015 for ESPAD, further confirmed by an ESPAD validation study carried out in 2016. The observed declines in alcohol use among adolescents have been pronounced not only in the indicators of prevalence of alcohol use, but also in all the indicators of HED, these now reaching levels far below those observed at the beginning of the studies in mid-1990's. Nevertheless, despite the significant declines in alcohol use, the adolescents in the Czech Republic have kept the highest level of alcohol use in Europe $(84,85)$.

While the proportion of alcohol-attributable deaths in total deaths decreased slightly between 2010 (5.6\%) and $2016(5.3 \%)$ globally (2), alcohol-related mortality in the Czech Republic, at least measured by the conditions with $\mathrm{AAF}=100 \%$, is on increase. The alcohol-related burden disproportionally affects predominantly men and the substantial part of mortality burden occurs in population aged 50 years and older, however, as shown also globally alcohol is a leading risk in younger age groups under 50 years, where external causes such as injuries and self-harm play major role (3).

That is one of the reasons why policy measures targeting alcohol use and alcohol availability are often focused on adolescents and children and young adults and on the contrary, persons over 65 years are not regarded as important population group. However, alcohol consumption including heavy alcohol use is comparatively prevalent in older age groups and some local surveys indicate, that especially retired men can be the population group with the largest consumed quantities of alcohol (83). As found also in the Czech data, people over 65 with positive alcohol consumption have higher risk of death, especially for external causes of death - drowning is more common in older people with alcohol intoxication (86).

The substantial proportion of alcohol-related burden in Europe (77\%) can be attributed to heavy drinking including alcohol dependence (17). Recent reviews also show that people with alcoholuse disorders have 3-4 fold higher risk of death as compared with general population and that the risks are even higher in population in formal treatment $(87,88)$. Because the level of heavy alcohol use and heavy episodic drinking in the Czech Republic is very high within European context, substantial impact of heavy alcohol use on morbidity and mortality can be assumed in the Czech Republic. Recent analysis showed 24.2 potential years of life lost (PYLL) in one deceased alcohol dependent individual (89).

Alcohol also contributes to social inequalities. However, whereas individuals in lower socioeconomic status (SES) groups report consuming the same quantity of alcohol or less than those in higher SES groups, rates of alcohol-related morbidity and mortality in lower SES groups are higher. This has been referred to as the "alcohol harm paradox". Possible explanations for the alcohol harm paradox include socioeconomic differences in patterns of drinking (e.g. greater prevalence of harmful alcohol consumption, as well as binge drinking in lower SES groups), syndemic effect of other health risky behaviour such as smoking, excess weight and poor diet/exercise, and underestimation of consumption levels and alcohol-related harms among individuals in more deprived communities. However, to date there is no comprehensive explanation for the alcohol harms paradox $(90,91)$.

Economic costs associated with use of alcohol consumption are substantial and estimated to be $1.3-3.3 \%$ of GDP of middle- and high-income countries (92), the proportion corresponding to recent estimates in the Czech Republic indicating 1.2\% of GDP (80).

The most cost-effective alcohol policies ("best buys") include pricing policies and marketing restrictions (93). However, reliable data indicate that population coverage of regulations on physical availability and restrictions on alcohol marketing are very low worldwide and policies often target specific population groups such as pregnant women or minors. However, alcohol-control policies need to be revised worldwide, refocusing on efforts to lower overall population-level consumption (3). Among the challenges in reducing the use of alcohol are weak political commitment, the influence of powerful commercial interests which go against effective alcohol control policies, and strong drinking traditions in many cultures (2). Alcohol has an exceptional status in public health policies worldwide which have resulted in acceptance of high alcohol-related harms, exemptions from key food regulatory measures and international conventions regulating other psychoactive substances (94).

Political commitment and strategic action in alcohol-control policy was insufficient in the Czech Republic until recently (95). However, there has been a recent progress in integrating alcohol into national substance-related policy since 2014 and the first ever alcohol-control action plan was adopted by the government in 2015. High level of alcohol consumption in the Czech Republic has to be seen also in context of broader socio-cultural and political context. Liberal alcohol-control policy was implemented in the Czech Republic particularly after political transition in 1990. Liberalization of social life together with considerable decline of alcohol prices due to re-privatization of alcohol production and market contributed to an increase of the alcohol consumption in the Czech Republic (96). The Czech Republic is known for liberal approach towards alcohol consumption and for the widespread availability of cheap alcohol beverages (97). The liberal approach and attitudes were not affected even after outbreak of methanol poisonings between 2012-2014 resulting from illegally produced alcoholic beverages contaminated by methanol (98).

\section{Limitations}

Alcohol situation is not systematically monitored in the Czech Republic in the entire scope of the phenomenon and thus this review suffers from incompleteness of data especially on morbidity, mortality and alcohol-related social consequences. Also, some data presented can reflect just partial part of the picture since for example substantial portion of morbidity may not be reported in in-patient data and may remain underreported. As regards the social burden and especially alcohol harms to others, routine data are very scarce. However, presented data on crime statistics, domestic violence or COI analysis show that social burden of alcohol is substantial. Also according to the National 
Survey on Substance Use, alcohol-related social harm is quite prevalent since negative impact of alcohol consumption in the last 12 months was according to the Adverse Social Consequences scale (41) reported by $19.4 \%$ of the population aged $15-64$ years (28.8\% males and $11.2 \%$ females), including primarily financial problems $(12.9 \%)$, family problems $(7.4 \%)$, and impact on relations with friends and social life (5.7\%) (99).

Quality and reliability of the routine data should be carefully evaluated since under-reporting is likely in some alcohol-related conditions and causes of deaths with $\mathrm{AF}=100 \%$. For example, as regards foetal alcohol spectrum disorders (FASD), there are single cases reported annually in the Czech Republic. Taking into account estimated global prevalence of $0.8 \%$ FASD in a general population (100) and high level of heavy alcohol consumption in the Czech Republic, hundreds of cases a year could be expected.

It should be also born in mind, that presented trend data on morbidity and mortality do not represent the full picture of alcohol-related health burden in the Czech Republic since they do not cover the most prevalent conditions with AAF $<100 \%$, such as cardiovascular diseases and cancers. Also, the presented 2016 COI study does not include full spectrum of alcohol-related health conditions (such as stroke).

\section{CONCLUSION}

Alcohol consumption as well as prevalence of heavy episodic drinking in the Czech Republic belongs among the highest globally. This unfavourable situation remains unchanged in recent years in the adult population, with signs of slight increases in heavy alcohol use. On the other hand, declines in alcohol use have been recently observed among children and adolescents. Available data on alcohol-related morbidity indicate stable situation, though alcohol-related mortality is increasing. Economic costs of alcohol consumption reach the level of middle- and highincome countries on the lower side of the range. Available data, taking into account insufficient implementation of recommended alcohol policy measures, indicate rather underestimation of real magnitude of alcohol-related problems in the Czech Republic. Ongoing monitoring system of alcohol use and its consequences should be established and evidence-based measures in alcohol policy should be increasingly implemented.

\section{Acknowledgements}

This paper was supported by the Ministry of Health of the Czech Republic, grant Nr. 16-28157A, the Charles University institutional support Progres Nr. Q06/LF1; the project Nr. LO1611 with a financial support from the Ministry of Education, Youth, and Sports of the Czech Republic under the NPU I program, and by the Czech Health Research Council, Grant No. 16-31333A.

\section{Conflict of Interests}

None declared

\section{REFERENCES}

1. GBD 2016 Risk Factors Collaborators. Global, regional, and national comparative risk assessment of 84 behavioural, environmental and occupational, and metabolic risks or clusters of risks, 1990-2016: a sys- tematic analysis for the Global Burden of Disease Study 2016. Lancet. 2017;390(10100):1345-422.

2. World Health Organization. Global status report on alcohol and health 2018. Geneva: WHO; 2018.

3. GBD 2016 Alcohol Collaborators. Alcohol use and burden for 195 countries and territories, 1990-2016: a systematic analysis for the Global Burden of Disease Study 2016. Lancet. 2018;392(10152):1015-35.

4. Zima T. Alcohol Abuse. EJIFCC. 2018;29(4):285-9.

5. Rehm J. The risks associated with alcohol use and alcoholism. Alcohol Res Health. 2011;34(2):135-43.

6. World Health Organisation. Global alcohol-attributable fractions for deaths, DALYs and YLDs by disease/injury 2012 [Internet]. Geneva: WHO [cited 2019 Jun 2.]. Available from: https://www.who.int/substance abuse/facts/alcohol attributable fractions global/en/.

7. Praud D, Rota M, Rehm J, Shield K, Zatonski W, Hashibe M, et al. Cancer incidence and mortality attributable to alcohol consumption. Int J Cancer. 2016;138(6):1380-7.

8. Rehm J, Shield KD, Roerecke M, Gmel G. Modelling the impact of alcohol consumption on cardiovascular disease mortality for comparative risk assessments: an overview. BMC Public Health. 2016;16:363. doi: 10.1186/s12889-016-3026-9.

9. Room R. Concepts and items in measuring social harm from drinking. $J$ Subst Abuse. 2000;12(1-2):93-111.

10. Gmel G, Rehm J. Harmful alcohol use. Alcohol Res Health. 2003;27(1):52-62.

11. Edman J. Harm to others - Rediscovered or Eternal? Nordic Studies on Alcohol and Drugs. 2016;33(5-6):479-81.

12. Room R, Laslett A-M, Jiang H. Conceptual and methodological issues in studying alcohol's harm to others. Nordic Studies on Alcohol and Drugs. 2016;33(5-6):455-78.

13. Sampson PD, Streissguth AP, Bookstein FL, Barr HM. On categorizations in analyses of alcohol teratogenesis. Environ Health Perspect. 2000;108 Suppl 3:421-8.

14. Vorgias D, Bernstein B. Fetal Alcohol Syndrome. In: StatPearls [Internet]. Treasure Island: StatPearls Publishing LLC.; 2018 [cited 2019 Jul 10]. Available from: https://www.ncbi.nlm.nih.gov/books/NBK448178/.

15. Rehm J, Marmet S, Anderson P, Gual A, Kraus L, Nutt DJ, et al. Defining substance use disorders: do we really need more than heavy use? Alcohol Alcohol. 2013;48(6):633-40.

16. Jayasekara H, English DR, Room R, MacInnis RJ. Alcohol consumption over time and risk of death: a systematic review and meta-analysis. Am J Epidemiol. 2014;179(9):1049-59.

17. Rehm J, Shield KD, Gmel G, Rehm MX, Frick U. Modeling the impact of alcohol dependence on mortality burden and the effect of available treatment interventions in the European Union. Eur Neuropsychopharmacol. 2013;23(2):89-97.

18. Rehm J, Anderson P, Gual A, Kraus L, Marmet S, Nutt DJ, et al. The tangible common denominator of substance use disorders: a reply to commentaries to Rehm et al. (2013a). Alcohol Alcohol. 2014;49(1):118-22.

19. Irving HM, Samokhvalov AV, Rehm J. Alcohol as a risk factor for pancreatitis. A systematic review and meta-analysis. JOP. 2009;10(4):387-92.

20. Rehm J, Taylor B, Mohapatra S, Irving H, Baliunas D, Patra J, et al. Alcohol as a risk factor for liver cirrhosis: a systematic review and metaanalysis. Drug Alcohol Rev. 2010;29(4):437-45.

21. Gallagher C, Hendriks JML, Elliott AD, Wong CX, Rangnekar G, Middeldorp ME, et al. Alcohol and incident atrial fibrillation - a systematic review and meta-analysis. Int J Cardiol. 2017;246:46-52.

22. Taylor B, Irving HM, Baliunas D, Roerecke M, Patra J, Mohapatra S, et al. Alcohol and hypertension: gender differences in dose-response relationships determined through systematic review and meta-analysis. Addiction. 2009;104(12):1981-90.

23. Roerecke M, Rehm J. Irregular heavy drinking occasions and risk of ischemic heart disease: a systematic review and meta-analysis. Am J Epidemiol. 2010;171(6):633-44.

24. Patra J, Taylor B, Irving H, Roerecke M, Baliunas D, Mohapatra S, et al. Alcohol consumption and the risk of morbidity and mortality for different stroke types - a systematic review and meta-analysis. BMC Public Health. 2010;10:258. doi: 10.1186/1471-2458-10-258.

25. Lonnroth K, Williams BG, Stadlin S, Jaramillo E, Dye C. Alcohol use as a risk factor for tuberculosis - a systematic review. BMC Public Health. 2008;8:289. doi: 10.1186/1471-2458-8-289.

26. Rehm J, Samokhvalov AV, Neuman MG, Room R, Parry C, Lonnroth $\mathrm{K}$, et al. The association between alcohol use, alcohol use disorders and tuberculosis (TB). A systematic review. BMC Public Health. 2009;9:450. doi: $10.1186 / 1471-2458-9-450$. 
27. Samokhvalov AV, Irving HM, Rehm J. Alcohol consumption as a risk factor for pneumonia: a systematic review and meta-analysis. Epidemiol Infect. 2010;138(12):1789-95.

28. Cherpitel CJ, Ye Y, Bond J, Borges G, Monteiro M. Relative risk of injury from acute alcohol consumption: modeling the dose-response relationship in emergency department data from 18 countries. Addiction. 2015;110(2):279-88.

29. Pelucchi C, Tramacere I, Boffetta P, Negri E, La Vecchia C. Alcohol consumption and cancer risk. Nutr Cancer. 2011;63(7):983-90.

30. de Menezes RF, Bergmann A, Thuler LC. Alcohol consumption and risk of cancer: a systematic literature review. Asian Pac J Cancer Prev. 2013;14(9):4965-72.

31. Gmel G, Rehm J, Room R, Greenfield TK. Dimensions of alcoholrelated social and health consequences in survey research. J Subst Abuse. 2000;12(1-2):113-38.

32. Rehm J, Baliunas D, Borges GL, Graham K, Irving H, Kehoe T, et al The relation between different dimensions of alcohol consumption and burden of disease: an overview. Addiction. 2010;105(5):817-43.

33. Gmel G, Gutjahr E, Rehm J. How stable is the risk curve between alcoho and all-cause mortality and what factors influence the shape? A precisionweighted hierarchical meta-analysis. Eur J Epidemiol. 2003;18(7):631-42.

34. Vahtera J, Poikolainen K, Kivimaki M, Ala-Mursula L, Pentti J. Alcohol intake and sickness absence: a curvilinear relation. Am J Epidemiol. 2002;156(10):969-76

35. Fehringer G, Brenner DR, Zhang ZF, Lee YA, Matsuo K, Ito H, et al Alcohol and lung cancer risk among never smokers: A pooled analysis from the international lung cancer consortium and the SYNERGY study. Int J Cancer. 2017;140(9):1976-84.

36. Holmes MV, Dale CE, Zuccolo L, Silverwood RJ, Guo Y, Ye Z, et al. Association between alcohol and cardiovascular disease: Mendelian randomisation analysis based on individual participant data. BMJ 2014;349:g4164. doi: https://doi.org/10.1136/bmj.g4164.

37. Chikritzhs T, Stockwell T, Naimi T, Andreasson S, Dangardt F, Liang W. Has the leaning tower of presumed health benefits from 'moderate' alcohol use finally collapsed? Addiction. 2015;110(5):726-7.

38. Stockwell T, Zhao J, Panwar S, Roemer A, Naimi T, Chikritzhs T. Do "moderate" drinkers have reduced mortality risk? A systematic review and meta-analysis of alcohol consumption and all-cause mortality. J Stud Alcohol Drugs. 2016;77(2):185-98.

39. Patra J, Taylor B, Rehm J. Deaths associated with high-volume drinking of alcohol among adults in Canada in 2002: a need for primary care intervention? Contemp Drug Probl. 2009;36(1-2):283-301.

40. Toma A, Pare G, Leong DP. Alcohol and cardiovascular disease: how much is too much? Curr Atheroscler Rep. 2017;19(3):13. doi: https:// doi.org/10.1007/s11883-017-0647-0.

41. Moskalewicz J, Sieroslawski J. Drinking Population surveys - guidance document for standardized approach. Final report for the Project Standardizing Measurement of Alcohol-Related Troubles - SMART. Warsaw: Institute of Psychiatry and Neurology; 2010.

42. Laslett AM, Room R, Ferris J, Wilkinson C, Livingston M, Mugavin J. Surveying the range and magnitude of alcohol's harm to others in Australia. Addiction. 2011;106(9):1603-11.

43. Ruprich J. Overview of national guidelines for moderate consumption of alcoholic beverages. Prague: NIPH; 2016. (In Czech.)

44. Miovský M. Positive effects of moderate alcohol use on human health: the futile search for a third side of the coin. Adiktologie. 2017;17(2):148-60.

45. World Health Organisation. International statistical classification of diseases and related health problems. Geneva: WHO; 2011.

46. American Psychiatric Association. Diagnostic and statistical manual of mental disorders. Washington, DC: American Psychiatric Association; 2013.

47. Babor TF, Higgins-Biddle JC, Saunders JB, Monteiro MG. AUDIT: the alcohol use disorders identification test. Guidelines for use in primary care. Geneva: WHO; 2001.

48. Mayfield D, McLeod G, Hall P. The CAGE questionnaire: Validation of a new alcoholism instrument. Am J Psychiatry. 1974(131):1121-3.

49. Cherpitel CJ, Ye Y, Bond J, Borges G, Cremonte M, Marais S, et al. Crossnational performance of the RAPS4/RAPS4-QF for tolerance and heavy drinking: data from 13 countries. J Stud Alcohol. 2005;66(3):428-32.

50. Ustun B, Compton W, Mager D, Babor T, Baiyewu O, Chatterji S, et al. WHO Study on the reliability and validity of the alcohol and drug use disorder instruments: overview of methods and results. Drug Alcohol Depend. 1997;47(3):161-9.

51. Lachner G, Wittchen HU, Perkonigg A, Holly A, Schuster P, Wunderlich $\mathrm{U}$, et al. Structure, content and reliability of the Munich-Composite In- ternational Diagnostic Interview (M-CIDI) substance use sections. Eur Addict Res. 1998;4(1-2):28-41.

52. Bloomfield K, Hope A, Kraus L. Alcohol survey measures for Europe: a literature review. Drugs (Abingdon Engl). 2013;20(5):348-60.

53. Ewing JA. Detecting Alcoholism. The CAGE Questionnaire. JAMA. 1984(252):1905-7.

54. Gabrhelik R, Nechanska B, Mravcik V, Skurtveit S, Lund IO, Handa M. A unique opportunity to study short and long term consequences in children prenatally exposed to illicit drugs and opioid maintenance treatment using Czech and Scandinavian registers. Cent Eur J Public Health. 2016;24(3):248-51.

55. Czech Statistical Office. Consumption of alcoholic beverages per capita in the Czech Republic. Prague: CZSO; 2019 [cited 2019 Apr 1]. Available from: https://www.czso.cz/csu/czso/cr_od_roku_1989_alkohol. (In Czech.)

56. Váňová A, Skývová M, Csémy L. Tobacco and alcohol use in the Czech Republic 2016. Prague: NIPH; 2017. (In Czech.)

57. Chomynová P, Mravčík V. National survey on substance use 2016. Zaostřeno. 2018;16(2):1-20. (In Czech.)

58. Chomynová P. National survey on substance use 2012. Smoking, alcohol and other drugs use in the general population. Zaostřeno na drogy. 2013;11(2):1-16. (In Czech.)

59. Běláčková V, Nechanská B, Chomynová P, Horáková M. General population survey on drug use and attitudes towards drug use 2008. Prague: Office of the Government of the Czech Republic; 2012. (In Czech.)

60. Institute of Health Information and Statistics of the Czech Republic. European Health Interview Survey in the Czech Republic EHIS 2008. Prague: IHIS CR; 2011. (In Czech.)

61. Institute of Health Information and Statistics of the Czech Republic. European Health Interview Survey in the Czech Republic (EHIS 2008) - Basic Information. Prague: IHIS CR; 2016. (In Czech.)

62. Daňková Š. EHIS 2014 - Basic survey results. Prague: IHIS CR; 2016 (In Czech.)

63. Rehm J, Room R, Monteiro M, Gmel G, Graham K, Rehn N, et al. Alcohol use. In: Ezzati M, Lopez AD, Rodgers A, Murray CJL, editors. Comparative quantification of health risks: global and regional burden of diseases attributable to selected major risk factors. Geneva: WHO; 2004. p. 959-1108

64. Devaux M, Sassi F. Alcohol consumption and harmful drinking: trends and social disparities across OECD countries. Paris: OECD Publishing; 2015.

65. Csémy L, Kážmér L, Dvořáková Z. Substance use among school-aged children: results of HBSC study 1994-2014. Presentation at regular meeting of Society for Addictive Diseases of Czech Medical Association JEP in Prague (2016 April 06). (In Czech.)

66. Chomynová P, Csémy L, Mravčík V. European School Survey Project on Alcohol and Other Drugs (ESPAD) 2015. Zaostřeno. 2016;14(5):1-16. (In Czech.)

67. Madarasová Gecková A, Dankulincová Z, Sigmundová D, Kalman M, editors. International report on health and lifestyle of children and schoolaged children based on the 2014 HBSC research. Košice, Olomouc: Palacký University Olomouc; 2016. (In Czech.)

68. Kohoutová I. Estimated impact of alcohol on mortality in the Czech Republic. Adiktologie. 2013;13(1):14-23. (In Czech.)

69. Czech Statistical Office. Demographic Yearbook 2005-2017. Prague: CZSO; 2018. (In Czech.)

70. Nešpor K, Csémy L. Domestic violence and alcohol. Čes a slov Psychiatr. 2005;101(3):174-5. (In Czech.)

71. Martinková M, Slavětínský V, Vlach J. Selected problems of domestic violence in the Czech Republic. Prague: IKSP; 2014. (In Czech.)

72. Pikálková S, Podaná Z, Buriánek J. Women as victims of partner violence. Prague: Slon; 2015. (In Czech.)

73. Dohnal D, Hokr Miholová P, Šprincová V, Domesová S. Analysis of the occurrence and latency of domestic violence in partnership. Prague: Office of the Government of the Czech Republic; 2017. (In Czech.)

74. Police Presidium of the Police of the Czech Republic. Statistical Surveys of Crime in 2017 (ESSK). Prague: Police Presidium of the Police of the Czech Republic; 2018. (In Czech.)

75. Directorate of Traffic Police Service of the Police Presidium of the Czech Republic. An overview of road accidents in the Czech Republic in 2016. Prague: Directorate of Traffic Police Service of the Police Presidium of the Czech Republic; 2017. (In Czech.)

76. Single E, Easton B, Collins D, Harwood H, Lapsley H, Maynard A, et al International Guidelines for Estimating the Costs of Substance Abuse. Ottawa: Canadian Centre on Substance Abuse; 1996. 
77. Single E, Collins D, Easton B, Harwood H, Lapsley H, Kopp P, et al. International Guidelines for Estimating the Costs of Substance Abuse. Ottawa: Canadian Centre on Substance Abuse; 2001.

78. Zábranský T, Běláčková V, Štefunková M, Vopravil J, Langrová M. Social costs of the use of alcohol, tobacco, and illegal drugs in the Czech Republic, 2007. Prague: Centre of Addictology, Department of Psychiatry of 1st Faculty of Medicine Charles University in Prague; 2011. (In Czech.)

79. Gustavsson A, Svensson M, Jacobi F, Allgulander C, Alonso J, Beghi E, et al. Cost of disorders of the brain in Europe 2010. Eur Neuropsychopharmacol. 2011;21(10):718-79.

80. Mlčoch T, Chadimová K, Doležal T. Social costs of the use of alcohol in the Czech Republic. Prague: iHETA; 2019. (In Czech.)

81. OECD. Tackling harmful alcohol use: economics and public health policy. OECD Publishing; 2015.

82. Fiala J, Sochor O, Klimusova H, Homolka M. Alcohol consumption in population aged 25-65 years living in the metropolis of South Moravia, Czech Republic. Cent Eur J Public Health. 2017;25(3):191-9.

83. Liška J, Mravčík V. Alcohol use in Jindřichovice, a municipality in the Karlovy Vary region. Adiktologie. 2018;18(1):59-62.

84. The ESPAD Group. ESPAD Report 2015. Results from the European School Survey Project on Alcohol and Other Drugs. Luxembourg: Publications Office of the European Union; 2016. 99 p.

85. Inchley J, Currie D, Young T, Samdal O, Torsheim T, Augustson L, et al., editors. Growing up unequal: gender and socioeconomic differences in young people's health and well-being. Health-Behaviour in School-aged Children (HBSC) Study: international report from the 2013/2014 survey. Copenhagen: WHO Regional Office for Europe; 2016.

86. Jurickova L, Ivanova K, Dobias M, Andrasik R, Ondra P. Manner of death of older people with regard to blood alcohol concentration. Cent Eur J Public Health. 2017;25(4):266-70.

87. Roerecke M, Rehm J. Alcohol use disorders and mortality: a systematic review and meta-analysis. Addiction. 2013(108):1562-78.

88. Laramee P, Leonard S, Buchanan-Hughes A, Warnakula S, Daeppen JB, Rehm J. Risk of all-cause mortality in alcohol-dependent individuals: a systematic literature review and meta-analysis. EBioMedicine. 2015;2(10):1394-404.

89. Nechanská B, Drbohlavová B, Csémy L. Structure of mortality of persons hospitalised for alcohol use disorders in the Czech Republic from 1994 to 2013. Adiktologie. 2017;17(2):84-91. (In Czech.)

90. Bellis MA, Hughes K, Nicholls J, Sheron N, Gilmore I, Jones L. The alcohol harm paradox: using a national survey to explore how alcohol may disproportionately impact health in deprived individuals. BMC Public Health. 2016;16:111. doi: 10.1186/s12889-016-2766-x.

91. Lewer D, Meier P, Beard E, Boniface S, Kaner E. Unravelling the alcohol harm paradox: a population-based study of social gradients across very heavy drinking thresholds. BMC Public Health. 2016;16:599. doi: 10.1186/s12889-016-3265-9.

92. Rehm J, Mathers C, Popova S, Thavorncharoensap M, Teerawattananon Y, Patra J. Global burden of disease and injury and economic cost attributable to alcohol use and alcohol-use disorders. Lancet. 2009;373(9682):222333.

93. Anderson P, Chisholm D, Fuhr DC. Effectiveness and cost-effectiveness of policies and programmes to reduce the harm caused by alcohol. Lancet. 2009;373(9682):2234-46.

94. Rehm J, Lachenmeier DW, Room R. Why does society accept a higher risk for alcohol than for other voluntary or involuntary risks? BMC Medicine. 2014;12(1):189. doi: 10.1186/s12916-014-0189-z.

95. Csémy L, Winkler P. Alcohol in the Czech Republic: trends in consumption, health consequences, and economic costs to society. Psychiatrie. 2012;16(4):210-6. (In Czech.)

96. Hnilicova H, Nome S, Dobiasova K, Zvolsky M, Henriksen R, Tulupova E, et al. Comparison of alcohol consumption and alcohol policies in the Czech Republic and Norway. Cent Eur J Public Health. 2017;25(2):14551.

97. Hnilicová H, Dobiášová K. Alcohol as an issue of the public health in the Czech Republic: facts and context. Časopis lékařů českých. 2018;157(5):248-53. (In Czech.)

98. Zakharov S, Pelclova D, Urban P, Navratil T, Diblik P, Kuthan P, et al. Czech mass methanol outbreak 2012: epidemiology, challenges and clinical features. Clin Toxicol (Phila). 2014;52(10):1013-24.

99. Mravčík V, Chomynová P, Grohmannová K, Janíková B, Tion Leštinová Z, Rous Z, et al. Annual report on drug situation in Czech Republic in 2016. Prague: Office of the Government of the Czech Republic; 2017. (In Czech.)

100.Lange S, Probst C, Gmel G, Rehm J, Burd L, Popova S. Global prevalence of fetal alcohol spectrum disorder among children and youth: a systematic review and meta-analysis. JAMA Pediatr. 2017;171(10):948-56.

Received March 1, 2019

Accepted in revised form July 10, 2019 